\title{
PELATIHAN PEMBELAJARAN DARING DIMASA \\ PANDEMI COVID-19 UNTUK GURU- GURU SD NEGERI 3 MELAYU MUARA TEWEH
}

\author{
Aulia Azizah \\ STIE Muara Teweh \\ E-mail : aulia.azizah11@gmail.com
}

\begin{abstract}
ABSTRAK
COVID-19 telah ditetapkan sebagai pandemi global dan memaksa pemerintah mengeluarkan aturan bagi guru-guru dan siswa untuk melakukan pembelajaran dari rumah yaitu melakukan pembelajaran secara online atau pembelajaran daring. Banyaknya guru-guru yang tidak menguasai media digital membuat pembelajaran dari cukup menyulitkan dan melihat hal tersebut dirasa perlunya dilakukan pelatihan bagi para guru-guru agar mereka bisa memperoleh kemudahan dalam melakukan pembelajaran daring. Tujuan Kegiatan Pengabdian Kepada Masyarakat ini adalah untuk melatih GuruGuru pada SD Negeri 3 Melayu Muara Teweh Mampu melaksanakan pembelajaran daring dengan media sederhana seperti grup di media sosial WhatsApp (WA), Telegram, aplikasi Zoom dan Google classroom. Lokasi Pengabdian Kepada masyarakat ini pada SD Negeri 3 Melayu Muara Teweh, Kabupaten Barito Utara, Kalimantan Tengah. Pelaksanaan kegiatan ini dari persiapan hingga pelaporan dilakukan selama 1 bulan yang dimulai pada awal bulan juni 2020 sampai 30 juni 2020 . Tim PKM telah berhasil melakukan kegiatan pelatihan dengan lancar pada SDN 3 Melayu Muara Teweh.Guru-guru pada SDN 3 Melayu Muara Teweh sudah bisa melakukan pembelajaran daring dengan memanfaatkan media sosial yang ada dan melakukan video conference dengan aplikasi Zoom dan google classroom. Guru-guru SDN 3 Melayu Muara Teweh sangat antusias melakukan pelatihan yang diberikan oleh pemateri.
\end{abstract}

Kata Kunci : Pengabdian;Pelatihan;Pembelajaran Daring; Covid-19; Guru

\section{ONLINE LEARNING TRAINING DURING THE COVID 19 PANDEMIC FOR TEACHERS SD NEGERI 3 MALAY MUARA TEWEH}

\begin{abstract}
COVID-19 has been declared a global pandemic and forces the government to issue regulations for teachers and students to do learning from home, namely learning online or learning online. The number of teachers who do not master digital media makes learning quite difficult and seeing this, it is felt that there is a need for training for teachers so that they can find it easy to do online learning. The purpose of this Community Service Activity is to train teachers at SD Negeri 3 Melayu Muara Teweh to be able to carry out online learning with simple media such as groups on social media WhatsApp (WA), telegram, zoom application and Google classroom. This community service location is at SD Negeri 3 Melayu Muara Teweh, North Barito Regency, Central Kalimantan. The implementation of this activity from preparation to reporting was carried out for 1 month starting at the beginning of June 2020 to June 30, 2020. The PKM team has successfully carried out training activities smoothly at SDN 3 Melayu Muara Teweh. Teachers at SDN 3 Melayu Muara Teweh can conduct online learning by utilizing existing social media and conducting video conferencing with the Zoom application and google classroom. The teachers of SDN 3 Melayu Muara Teweh were very enthusiastic about the training provided by the speakers.
\end{abstract}

Keywords: Community Service; Training; Online Learning; Covid-19; Teacher 
BAKTI BANUA : Jurnal Pengabdian Kepada Masyarakat

Volume 1 No. 2 November 2020

e-ISSN : 2722-3736

p-ISSN : 2722-7529

https://ejurnal.stimi-bjm.ac.id/index.php/BBJM/

\section{PENDAHULUAN}

Coronavirus Disease 2019 (COVID-19) telah ditetapkan sebagai pandemi global. Hal ini membuat beberapa negara menetapkan kebijakan untuk memberlakukan lockdown dalam rangka mencegah penyebaran virus corona. Di Indonesia sendiri, diberlakukan kebijakan Pembatasan Sosial Berskala Besar (PSBB) untuk menekan penyebaran virus ini.Karena Indonesia sedang melakukan PSBB, maka semua kegiatan yang dilakukan di luar rumah harus dihentikan sampai pandemi ini mereda. Sesuai dengan Surat Edaran Nomor 4 Tahun 2020 oleh Menteri Pendidikan dan Kebudayaan Republik Indonesia terkait tentang Pelaksanaan Kebijakan Pendidikan dalam Masa Darurat Penyebaran Coronavirus Disease (COVID-19). Beberapa pemerintah daerah memutuskan menerapkan kebijakan untuk meliburkan siswa kemudian mulai menerapkan metode belajar dengan sistem daring (dalam jaringan) atau online. Sistem pembelajaran daring merupakan sistem pembelajaran tanpa tatap muka secara langsung antara guru dan siswa tetapi dilakukan pertemuan melalui online yang menggunakan jaringan internet. Guru harus memastikan kegiatan belajar mengajar tetap berjalan, meskipun siswa berada di rumah. Sehingga guru dituntut dapat mendesain media pembelajaran sebagai inovasi dengan memanfaatkan media daring atau online.

Sistem pembelajaran daring dilaksanakan melalui perangkat personal computer (PC) atau laptop yang terhubung dengan koneksi jaringan internet. Guru dapat melakukan pembelajaran bersama diwaktu yang sama menggunakan grup di media sosial seperti WhatsApp (WA), telegram,aplikasi zoom, Google Classroom ataupun media lainnya sebagai media pembelajaran. Dengan demikian, guru dapat memastikan siswa mengikuti pembelajaran dalam waktu yang bersamaan, meskipun di tempat yang berbeda.Hal ini memberikan tantangan baru untuk para tenaga pendidik, sistem pembelajaran daring harus dijalani di masa pandemi ini yang kemudian memaksa para guru-guru untuk lebih aktif dan kreatif dalam dunia digital untuk memberikan materi dan menyajikan bahan ajar mereka untuk para siswa agar menarik dan sesuai karakter siswa. Pembelajaran daring yang memaksa para guruguru untuk paham dunia digital menjadi tantangan tersendiri untuk para guru-guru senior yang cukup tertinggal dengan perkembangan era digital. SD Negeri 3 Melayu merupakan sekolah yang memiliki tenaga pendidik yang hampir $70 \%$ guru-gurunya berusia diatas 40 tahun dan tidak terlalu aktif pada dunia digital sehingga dirasa perlu diberikan pelatihan pelaksanaan pembelajaran daring terutama untuk menggunakan media yang sederhana seperti memanfaatkan group di media sosial WhatsApp (WA), telegram, aplikasi zoom dan Google classroom.

\section{Tujuan Pengabdian Kepada Masyarakat}

Tujuan Kegiatan Pengabdian Kepada Masyarakat ini adalah untuk melatih Guru-Guru pada SD Negeri 3 Melayu Muara Teweh Mampu melaksanakan pembelajaran daring dengan media sederhana seperti grup di media sosial WhatsApp (WA), telegram, aplikasi zoom dan Google classroom.

\section{Manfaat Pengabdian Kepada Masyarakat}

Manfaat yang diharapkan dari Kegiatan Pengabdian Kepada Masyarakat ini adalah Guru-Guru di SD Negeri 3 Melayu Muara Teweh Mampu melaksanakan pembelajaran daring dengan media sederhana seperti group di media sosial WhatsApp (WA), telegram, aplikasi zoom dan Google classroom.

\section{METODE}

\section{Lokasi Pengabdian}

Lokasi Pengabdian Kepada masyarakat ini pada SD Negeri 3 Melayu Muara Teweh, Kabupaten Barito Utara, Kalimantan Tengah

\section{Ruang Lingkup Pengabdian}

Adapun ruang lingkup kegiatan pengabdian kepada masyarakat ini adalah untuk meningkatkan kemampuan guru-guru SD Negeri 3 Melayu Muara Teweh dalam bidang pemanfaatan dunia digital 
BAKTI BANUA : Jurnal Pengabdian Kepada Masyarakat

Volume 1 No. 2 November 2020

e-ISSN : 2722-3736

p-ISSN : 2722-7529

https://ejurnal.stimi-bjm.ac.id/index.php/BBJM/

dalam melakukan pembelajaran daring, sehingga guru-guru SD Negeri 3 Melayu Muara Teweh mampu memanfaat media sederhana seperti grup di media sosial WhatsApp (WA), telegram, aplikasi zoom dan Google classroom untuk melakukan proses belajar mengajar.

\section{Kelompok Sasaran}

Pelatihan ini berfokus pada Guru-Guru SD Negeri 3 Melayu Muara Teweh sebanyak 13 orang.

\section{Metode Pengabdian}

Metode yang dilakukan dalam kegiatan ini adalah pemaparan materi yang terdapat pada Modul, diskusi tanya jawab dan praktik langsung materi yang ada pada modul. Pemaparan materi adalah menjelaskan pengertian berbagai media yang bisa digunakan dalam melakukan pembelajaran daring. Tanya jawab dilakukan untuk para peserta yang masih belum mengenai materi yang yang disampaikan. Kemudian melakukan praktek cara membuat akun sosial media WhatsApp (WA), telegram, aplikasi zoom dan Google classroom dan dilanjutkan dengan praktek cara sharing materi bahan ajar melalui media WhatsApp (WA) dan telegram. Melakukan praktek cara membuat kelas dan pertemuan secara onlain dengan aplikasi zoom dan Google classroom.

\section{Rencana Evaluasi}

Proses Kegiatan Pelatihan dilakukan dengan latihan secara langsung dan dibimbing langsung oleh pemateri, setiap materi yang sudah diajarkan dilakukan evaluasi dengan memberikan penugasan kepada peserta untuk melakukan simulasi sharing materi pada WhatsApp (WA) dan telegram kemudian membuat akun dan kelas online sendiri pada aplikasi zoom dan Google classroom.

\section{Rencana dan Jadwal Kerja}

Pelaksanaan kegiatan ini dari persiapan hingga pelaporan dilakukan selama 1 bulan yang dimulai pada awal 2 juni 2020 sampai 30 juni 2020. Kegiatan pelatihan dilaksanakan selamat satu hari pada tanggal 22 Juni 2020 dimulai dari jam 08.00 WIB sampai selesai.

\section{HASIL DAN PEMBAHASAN \\ Hasil Pelaksanaan Kegiatan}

Bentuk konkrit dari kegiatan yang sudah dilakukan sehingga kegiatan pengabdian kepada masyarakat ini bisa berlangsung adalah 1). Melakukan identifikasi kebutuhan pelatihan bagi para guru-guru di SDN 3 Melayu Muara Teweh dengan berdiskusi langsung kepada kepala sekolah dan beberapa guru. 2). Melakukan Perencanaan Kegiatan dan penentuan Jadwal Kegiatan 3). Pembuatan Modul 4). Melakukan pelatihan dengan pemberian materi dan praktek langsung.

Dilihat dari hasil pengamatan dan evaluasi kegiatan yang dilakukan di SDN 3 Melayu yang dilakukan selama 1 hari, dapat dilihat bahwa kegiatan pelatihan tersebut dianggap berhasil dan mencapai indikator keberhasilan sebagai berikut :

a. Guru- Guru bisa membuat group pada media WhatsApp (WA) dan telegram dan membagikan materi bagi para siswa

b. Guru-Guru bisa membuat akun aplikasi zoom dan Google classroom.

c. Guru-Guru bisa membuat kelas online sendiri pada akun aplikasi zoom dan Google classroom masing-masing.

\section{Faktor Pendukung}

Faktor pendukung keberhasilan kegiatan pelatihan ini adalah dukungan dari STIE Muara Teweh yang telah ,mendukung dengan meminjamkan peralatan untuk media presentasi. Selain itu, kesediaan para guru-guru SDN 3 Melayu untuk meluangkan waktu mengikuti pelatihan ini.

\section{Faktor Penghambat}


BAKTI BANUA : Jurnal Pengabdian Kepada Masyarakat

Volume 1 No. 2 November 2020

e-ISSN : 2722-3736

p-ISSN : 2722-7529

https://ejurnal.stimi-bjm.ac.id/index.php/BBJM/

Tidak ditemukan faktor penghambat yang cukup berarti dalam kegiatan ini karena semua kegiatan berjalan dengan lancar, hanya ada sedikit perlu penyesuaian pada pengaturan jadwal kegiatan karena untuk menyesuaikan jadwal pemateri dan guru-guru peserta pelatihan.

\section{Evaluasi}

Evaluasi dilakukan pada hasil kegiatan yang sudah dilakukan dan dinilai dari penguasaan materi dan penyelesaian tugas. Sasaran kegiatan ini adalah meningkatkan kemampuan guru-guru SDN Melayu 3 untuk bisa melaksanakan pembelajaran daring dengan media sederhana dan aplikasi yang tersedia secara gratis. Pelatihan ini melibatkan 1 orang instruktur dan sekaligus pemateri yang memiliki keahlian bidang penggunaan media sosial dan membuat akun media sosial. Materi disampaikan dengan modul baik dalam bentuk soft maupun hard copy kepada peserta sehingga dapat memudahkan pemateri dalam menjelaskan modul dan rencana kegiatan pelaksanaan pelatihan.

Berdasarkan hasil pelatihan, terlihat guru-guru mengikuti pelatihan dengan sangat antusias. Hal ini juga terlihat setiap ada hal yang belum jelas disampaikan instruktur, guru langsung menanyakan kepada instruktur. Beberapa kesulitan kecil, semisalnya sebagian kecil guru belum memiliki sosial media yang diajarkan, sehingga harus mengajari dulu cara mendownload dan menginstal sosial media pada handphone dan laptop masing-masing. Setelah semua guru sudah memiliki aplikasi yang akan diajarkan, hal pertama yang dipastikan lagi adalah para guru sudah memiliki email masing-masing dan jika ada yang belum memiliki maka instruktur membimbing untuk melakukan pembuatan akun email pribadi. Setelah semua sudah memiliki email dan bisa membuat akun pada aplikasi yang di ajarkan guru-guru diberikan tugas sebagai bahan evaluasi sejauh mana pemahaman merekaa dengan materi yang sudah di ajakan, tugas yang diberikan yaitu setiap orang harus praktek melakukan sharing materi dan pemberian tugas pas group belajar siswa, kemudian guruguru juga harus praktek melakukan video conference dengan menggunakan aplikasi Zoom dan Google Classroom.

Melihat dari kegiatan yang sudah dilakukan, apa yang dialami guru-guru pada SDN 3 Melayu yaitu masih kurangnya penguasaan media sosial dalam menunjang pembelajaran daring juga dialami kebanyakan guru-guru di daerah dan lebih parah lagi bagi guru-guru yang mengajar pada daerah terpencil yang mengalami kesulitan sinyal selular, sehingga dianggap masih perlunya banyak pelatihan semacam ini untuk para guru-guru untuk meningkatkan kemampuan mereka dalam menunjang pembelajaran daring di masa pandemi Covid-19 saat ini.

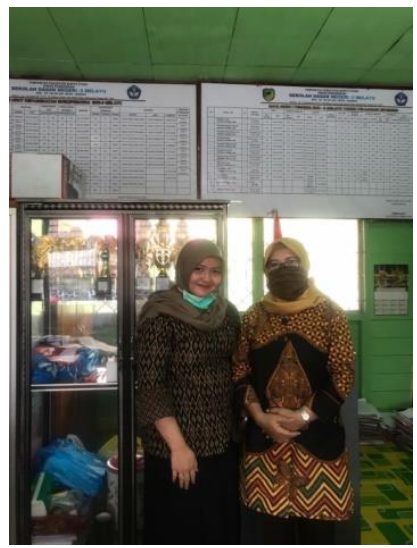

Gambar 1. Pertemuan bersama kepala sekolah SDN 3 Melayu untuk mementukan jadwal kegiatan

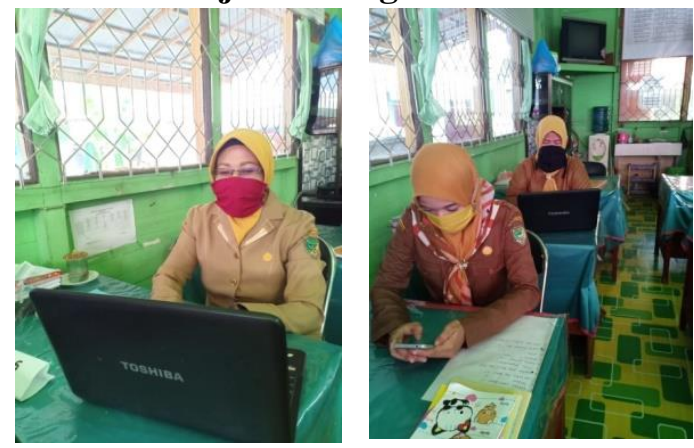


BAKTI BANUA : Jurnal Pengabdian Kepada Masyarakat

Volume 1 No. 2 November 2020

e-ISSN : 2722-3736

p-ISSN : 2722-7529

https://ejurnal.stimi-bjm.ac.id/index.php/BBJM/

\section{SIMPULAN}

\section{Gambar 2. Kegiatan pelatihan bersama guru-guru SDN 3 Melayu Muara Teweh}

Kesimpulan dari Kegiatan Pengabdian kepada Masyarakat ini adalah :

1. Tim PKM telah berhasil melakukan kegiatan pelatihan dengan lancar pada SDN 3 Melayu Muara Teweh.

2. Guru-guru pada SDN 3 Melayu Muara Teweh sudah bisa melakukan pembelajaran daring dengan memanfaatkan media sosial yang ada dan melakukan video conference dengan aplikasi Zoom dan google classroom.

3. Guru- guru SDN 3 Melayu Muara Teweh sangat antusias melakukan pelatihan yang diberikan oleh pemateri.

4. Terjalin kerjasama yang baik antara tim PKM STIE Muara Teweh dan SDN 3 Melayu Muara Teweh.

\section{UCAPAN TERIMAKASIH}

Ucapan terima kasih kepada kepala sekolah dan guru-guru, SDN 3 Melayu Muara Teweh yang telah memberikan izin untuk melakukan Kegiatan Pengabdian Kepada Masyarakat ini. Tidak lupa juga ucapan terima kasih kepada STIE Muara Teweh yang telah mendukung terlaksananya kegiatan ini dan sebagai pemberi tugas kepada tim PKM ini.

\section{DAFTAR PUSTAKA}

Alwi, S. (2017). Problematika guru dalam pengembangan media pembelajaran. ITQAN: Jurnal IlmuIlmu Kependidikan, 8(2), 145-167.

Hadi, F., Syafi'i, A., \& Isgandi, Y. (2020). Pelatihan Penerapan Pembelajaran Daring Interaktif Bagi Guru-Guru SD Al Islam Morowudi, Gresik. To Maega: Jurnal Pengabdian Masyarakat, 3(2), $142-149$.

Iqbal, T., \& Akbar, R. (2020). PELATIHAN INTERNET DAN POWERPOINT UNTUK GURUGURU DI SEKOLAH DASAR NEGERI 19 KOTA SABANG. Bakti Banua: Jurnal Pengabdian Kepada Masyarakat, 1(1), 18-24.

Kadarisma, G., \& Ahmadi, Y. (2019). Pelatihan Penggunaan Media Pembelajaran Berbasis ICT Kepada Guru Sekolah Dasar. Amal Ilmiah: Jurnal Pengabdian Kepada Masyarakat, 1(1), 3540.

Kurniawan, B., \& Purnomo, A. (2020). Pelatihan Penggunaan Aplikasi Google Classroom Sebagai Upaya Peningkatan Pembelajaran Online Bagi Guru Matapelajaran IPS MTs Di Kota Malang. International Journal of Community Service Learning, 4(1), 1-9.

Negara, H. R. P., Ibrahim, M., \& Etmy, D. (2020). Pelatihan Pembelajaran Daring (Google Classroom) bagi Guru MTs dan MI Nurul Yaqin Kelanjur. JPMB: Jurnal Pemberdayaan Masyarakat Berkarakter, 3(1), 66-79.

Rifiana Arief, E. (2012). Usaha Peningkatan Profesionalisme Guru Melalui Pelatihan Internet dan ELearning Sekolah. In Proceeding Seminar Nasional Pendidikan Teknik Elektro. 
BAKTI BANUA : Jurnal Pengabdian Kepada Masyarakat

Volume 1 No. 2 November 2020

e-ISSN : 2722-3736

p-ISSN : 2722-7529

https://ejurnal.stimi-bjm.ac.id/index.php/BBJM/

Simangunsong, A., Hasugian, P. S., \& Marpaung, J. F. (2018). PKM: Pelatihan Internet Dan Power Point Untuk Siswa Dan Guru-Guru SMA Kemala Bhayangkara 1 Medan. TRIDARMA: Pengabdian Kepada Masyarakat (PkM), 1(2, Nopembe), 66-70.

Suhara, A. M., Firmansyah, D., \& Permana, I. (2020). PELATIHAN PEMBELAJARAN ELEARNING SOCRATIVE PADA GURU BAHASA INDONESIA KABUPATEN SUBANG. Abdimas Siliwangi, 3(2), 415-422.

Yudhistiro, K., Sumartono, D. A. P., Prasetya, D. A., Nurdewanto, B. N., \& Sonalitha, E. S. (2020). Network Education Sekolah Dasar Islam Mohammad Hatta Kota Malang. JAPI (Jurnal Akses Pengabdian Indonesia), 4(2), 92-97.

Wicaksono, V. D., \& Rachmadyanti, P. (2017). Pembelajaran blended learning melalui google classroom di sekolah dasar. 